\title{
The European Commission's Report on Company Income Taxation: What the EU Can Learn from the Experience of the US States
}

Walter Hellerstein

UGA School of Law, wallyh@uga.edu

bepress SSRN

\section{Repository Citation}

Walter Hellerstein, The European Commission's Report on Company Income Taxation: What the EU Can Learn from the Experience of the US States (2004),

Available at: https://digitalcommons.law.uga.edu/fac_artchop/724

This Article is brought to you for free and open access by the Faculty Scholarship at Digital Commons @ University of Georgia School of Law. It has been accepted for inclusion in Scholarly Works by an authorized administrator of Digital Commons @ University of Georgia School of Law. Please share how you have benefited from this access For more information, please contact tstriepe@uga.edu. 


\title{
The European Commission's Report on Company Income Taxation: What the EU Can Learn from the Experience of the US States
}

\author{
WALTER HELLERSTEIN \\ University of Georgia Law School, Athens, 6A 30602-6012 \\ CHARLES E. MCLURE, JR. \\ Hoover Institution, Stanford University, CA 94305-6010, USA
}

mclure@hoover.stanford.edu

\begin{abstract}
The European Union Commission has proposed using consolidated base taxation and formulary apportionment to tax the EU-source income of multinational companies. This paper examines US state experience with a similar approach. Despite some positive lessons, especially the need to consolidate income of affiliated companies, lessons are mostly negative, especially regarding the choice of apportionment formula, the use of economic criteria to define the group whose income is to be consolidated, and complexity caused by lack of uniformity. US experience says nothing about using value added to apportion income-an approach that is conceptually attractive, but subject to transfer pricing problems.
\end{abstract}

Keywords: company income tax, formulary apportionment, home state taxation

JEL Code: H20, H71, H87

\section{Introduction}

The European Union (EU) is contemplating a shift from a system of dividing the EUsource income of multinational companies based on separate accounting and the arm's length standard (SA/ALS) to one based on consolidated base taxation (CBT) with formulary apportionment (FA). It is common to note, as the EU Commission ("the Commission") has done, that the states of the United States (US) provide experience with FA from which the EU can learn. (Commission of the European Communities, 2002, pp. 498-504.) This paper describes and appraises relevant aspects of that experience. While there are some positive lessons, especially regarding the need to consolidate or combine the income of affiliated groups of companies, and perhaps how to do it, the lessons are mostly negative, especially regarding the choice of an apportionment formula and the complexity caused by the lack of uniformity. As should so often be the case when one peeks across borders in search of "best practice," the answer one gets is predominantly "don't do what we do." US experience sheds no direct light on the most novel idea found in the Commission's report, examined briefly in Section 4.4, the suggestion that apportionment might be based on value added at origin. 
We take as given the case for using a formula-based system to divide consolidated income earned within the EU among Member States, but assume, as does the Commission, that Member States will not apply formulary apportionment on a worldwide basis. We do not describe well-known problems with the current system - the complexity of complying with 15 (soon to be 25) national tax systems; the need to distinguish between types of income (e.g., business profits, dividends, interest, and royalties) and between the sourcing rules applicable to such types (e.g., for sale of goods, use of intangibles, and provision of services); the existence of withholding taxes on intra-EU payments of interest and royalties; the taxation of cross-border dividends; the possibility of utilizing separate entities for tax planning; the difficulty and burden of calculating, documenting, and monitoring transfer pricing and cost allocations (not to mention the fact that scientific accuracy may be conceptually impossible in some cases); and the need for cross-border loss-offsets and neutrality toward organizational form. (These are described, for example, in McLure and Weiner, 2000; UNICE, 2000; Commission of the European Communities, 2002, pp. 458-460; Gammie, Radaelli and Klemm, 2001; Cnossen, 2001; Mintz and Weiner, 2003; and Devereaux, 2004.) Nor do we describe economic distortions and various other problems associated with FA (described in Gordon and Wilson, 1986; Mintz and Weiner, 2003; McLure, 2002; and literature cited there) or comment on more drastic alternative solutions, such as that offered by Devereaux (2004) for a destination-based cash flow corporation tax.

The EU Commission has tabled four models for consideration; three of which would involve CBT and FA.

Home state taxation (HST): Each corporate group could, at its option, be taxed by all participating Member States under the tax rules of the Member State where the parent is headquartered.

Common consolidated base taxation (CCBT): Corporate groups could choose to utilize a tax base common to the participating Member States.

Harmonized tax base (HTB): Corporate groups would utilize a tax base common to all Member States. ${ }^{1}$

Tax rates would be set by Member States under all three of these models. (For further details, see Commission of the European Communities, 2001, or Devereaux, 2004).

HST and CCBT are generally considered to be the only politically feasible alternatives, as they would be optional for both Member States and taxpayers. HTB would likely run afoul of the requirement that tax provisions be approved unanimously by all Member States, as it would be mandatory and would involve complete uniformity of taxation throughout the EU, except for rates.

We discuss three key design issues - the definition of the tax base, the delineation of the taxable group, and the choice of the apportionment formula. We focus on CCBT rather than HST for several reasons. First, we believe that CCBT is the more desirable approach. (See Sørensen, 2003, and Mintz and Weiner, 2003.) Second, the definition of the tax base does not even arise under HST, and the definition of groups might not (see Commission of the European Communities, 2002, pp. 475-476). Finally, US experience is not helpful for appraising the key feature of HST, taxation based on the tax law of the jurisdiction of 
residence of group headquarters, since there is nothing analogous in the US. Most of the analysis would be equally applicable to HTB.

The various choices we discuss would affect the division of tax bases among Member States; we do not discuss the resulting revenue consequences. Nor do we discuss the economic effects of differences in taxes between Member States for, as Jack Mintz (2004) has said, company tax harmonization in the EU is "all about compliance" (see, however, the annexes to Commission of the European Communities, 2002; Mintz and Weiner, 2003).

\section{The Tax Base}

\subsection{The Definition of Taxable Income}

The definition of the income tax base is a central issue for design of the CCBT. However, beyond acceptance of the principle that the CCBT implies a single common base rather than a series of separate country tax bases and recognition that adoption of such a base would reduce complexity and other problems arising from the existence of separate tax bases, relatively little attention has been devoted to the precise contours of the new income tax base. To be sure, there is a widespread assumption that the new income tax base would incorporate common elements of preexisting individual country income tax bases and, perhaps, certain "best practices," such as the International Accounting Standards; see UNICE (2000). Yet it is recognized that important issues must be addressed, because financial accounting and tax accounting serve different purposes, the degree of "dependence" of tax accounting on financial accounting currently differs among Member States, and the treatment of particular elements of the income tax base (e.g., depreciation, goodwill, and capital gains) remains largely unexplored. See Commission of the European Communities (2003).

Despite the importance of the income tax base issue to the design of the CCBT, it is one on which the US subnational experience has little to offer. The signal characteristic of the American state corporate income tax base is its broad conformity to the federal corporate income tax (Hellerstein and Hellerstein, 1998, \ 7.02). Although the states possess substantial constitutional freedom to define taxable income as they wish, virtually every state with a corporate income tax requires that taxpayers begin their state tax calculation with federal taxable income determined after or (less commonly) before net operating losses and special deductions, due largely to pressure from taxpayers to simplify the system and thereby ease compliance and auditing burdens. Thus most of the significant overall "base" issues are exogenously determined for the states, generally with no more input from the states than from taxpayers. Consequently, there are no relevant "comparative federalism" lessons to be learned from the "experience" of how the 45 independent states that impose income taxes "got together" to determine a common income tax base. (The lesson that it is easier for sub-national jurisdictions to adopt a common base if a national base has already been defined does not seem to have much practical value to the EU.)

\subsection{The Tax Base Distinguished from the Apportionable Tax Base}

When we turn from the definition of the overall income tax base to the delineation of the apportionable tax base-that portion of the income tax base that is subject to 
apportionment-we encounter an issue that is central to US subnational corporate income taxation.

2.2.1. US Practice Under the Commerce and Due Process Clauses of the US Constitution, a state may tax only income produced by the taxpayer's activities with which the state has a substantial connection ("nexus," in US parlance) (Hellerstein, 1993, pp. 743-744). In short, the Constitution (as interpreted by the US Supreme Court) draws a sharp line between the taxpayer's federally determined income tax base and its "apportionable" income tax base. A state may not tax even an apportioned share of the taxpayer's income tax base with which it has no constitutionally cognizable connection. Accordingly, a state corporate taxpayer's determination of the portion of its tax base, as defined by the particular state, that is taxable in that state is normally a two-step process. First the taxpayer, acting pursuant to the Uniform Division of Income for Tax Purposes Act (UDITPA) or similar state statutes that reflect the foregoing constitutional restraints, divides its income into apportionable "business income," i.e., "income arising from transactions and activity in the regular course of the taxpayer's trade or business" and "nonbusiness income," i.e., "all income other than business income." Second, the taxpayer assigns the "nonbusiness" income to a particular state or state, based on the deemed source of the particular type of income (e.g., rentals assigned to situs of property, dividends assigned to commercial domicile). The balance of the income is apportioned by formula.

2.2.2. Lessons for the $\boldsymbol{E} \boldsymbol{U}$ Whether the state corporate income tax distinction between apportionable and allocable income contains valuable lessons for the design of the CCBT depends on the answers to two questions. First, does the distinction make sense from a tax policy perspective? Second, if the answer to the first question is "yes," is the added administrative burden of implementing the distinction worth the perceived benefits of increased accuracy of income assignment?

With respect to the first question, we believe that the distinction between apportionable "business income" and allocable "nonbusiness income" is justified from a tax policy perspective. Insofar as the tax systems of the American states and the Member States of the EU have as one of their principal objectives the taxation of income on a source basis, it makes sense to attribute income to the state of source when such state is readily identifiable. For example, there is no justification as a matter of principle for apportioning between States A and $\mathrm{B}$ income that a corporation earns from discrete activity conducted in State A merely because the corporation performs unrelated activity in State B. The principal reason for apportioning income that is taxable on a source basis, rather than specifically assigning it to its state of source, is that we don't know or cannot easily determine the source of the income. Apportionment is simply a reasonable, if "second-best," method for assigning income to the states of its source in the face of such uncertainty-a task the US Supreme Court has likened to "slicing a shadow."3

Notwithstanding our view that differentiating apportionable "business income" from allocable "nonbusiness income" is warranted as a matter of principle, our resolution of the second question - whether the burden of distinguishing between allocable and apportionable income is worth the candle of increased accuracy in sourcing such income-leads us 
to conclude that the EU would be better advised not to follow the US subnational practice and to treat a group's entire EU-source income as a single apportionable base.

First, despite the theoretical appeal of distinguishing between "business" and "nonbusiness" income, the distinction is notoriously difficult to implement and has been subject to considerable litigation in the US (Hellerstein and Hellerstein, 1998, $\uparrow$ 9.05; Hellerstein, 2001). Second, and more fundamentally, neither the place of commercial domicile nor any other proxy for corporate residence has a compelling claim that it constitutes the actual and exclusive source of most "nonbusiness income." Third, attribution of non-business income to the place of corporate residence would create incentives for member States to compete for the right to tax such income; the result might be a "race to the bottom" in the tax rates on non-business income and thus to opportunities for tax planning. Fourth, as a practical matter, for most taxpayers during most tax years, "business income" is almost certainly far more significant than "nonbusiness income."

\section{The Consolidated Group}

\subsection{Legal versus Economic Unity}

Perhaps the most fundamental question confronting the designers of a CCBT with respect to the appropriate definition of the consolidated group is whether to delineate the group in terms of legal or economic relationships. The consolidated group could be defined solely on the basis of legal control of the entities. For example, the group could be defined as all corporations linked by a specified degree of ownership (e.g., more than 50 percent direct or indirect ownership). Alternatively, the group could be defined in economic terms. For example, the group could be defined as all commonly controlled entities that constituted a single economically integrated business. Under this approach, a given corporate group—or even a single company - could be engaged in more than one activity. In that case, different apportionment formulas could apply to the various activities of a group of commonly controlled entities. For example, in the US a conglomerate engaged in oil and oil-related businesses, shipbuilding, packaging, manufacture of construction and farm equipment, and automotive parts has been found to be engaged in five distinct activities and can thus apply an apportionment formula that reflects the factors of each to the stream of income generated by each of those lines of business. ${ }^{4}$

When the group is defined in terms of a single economic unit, it is often referred to as a "unitary" group, at least in the context of American subnational taxation. Indeed, constitutional constraints on the taxing powers of the American states require that the mandatory application of formulary apportionment to a group of entities be confined to such an economically integrated or "unitary" group. According to the US Supreme Court, "the linchpin of apportionability in the field of state income taxation is the unitary business principle." ${ }^{5}$ This principle limits both the mandatory application of formulary apportionment to a group of affiliated entities and the analogous question of the mandatory application of formulary apportionment to the tax base of a single legal entity.

The US state practice with respect to the use of formulary apportionment of consolidated tax base is far from uniform. To be sure, because of the foregoing constitutional restraints on 
apportionability, all states are bound by a common set of legal restraints on the delineation of the consolidated group when they seek to require consolidated reporting. As we point out below, however, the "unitary business" principle is more uniform in theory than in practice. Moreover, nearly half the states with corporate income taxes do not require consolidated reporting at all, even for unitary affiliates (Hellerstein and Hellerstein, 2001, pp. 583-584). In these so-called "separate company reporting" states, formulary apportionment is applied only on a legal-entity-by-legal entity basis. Furthermore, although a bare majority of states with corporate income taxes provide for consolidated reporting, in a number of these states the consolidated filing is elective rather than mandatory, and the "unitary business" principle may not be a prerequisite to consolidated filing.

This brings us back to the essential design question: Which approach to delineating the consolidated group — one based on legal or economic interrelationships-recommends itself from a normative and a practical standpoint?

At first blush, the economic or "unitary" approach to the delineation of the consolidated group may appear to be superior to the legal or "ownership" approach. After all, the underlying rationale for the use of formulary apportionment for determining the source of income is that economic interrelationships among cross-border activities make it impossible to determine the source of income from such activities on the basis of separate geographic accounting. If we could determine where income was earned with precision and at reasonable costs by separate geographic accounting, there would be no justification for resorting to a "necessarily imperfect" "mathematical generalization" for making that determination. Consequently, because it is the immeasurable economic "flows of value" 8 between various components of a single economic enterprise that justify the use of formulary apportionment in the first place, such economic interrelationships should lay the foundation for determining the delineation of the group whose tax base is to be to be apportioned. If two commonly owned entities have no underlying economic ties with one another (apart from their ownership by a common parent), there does not appear to be any compelling public policy reason why their incomes should be lumped together and apportioned according to a formula reflecting the combined factors of the two unrelated businesses. $^{9}$

An economic approach to the delineation of the consolidated group, despite the theoretical case for it, raises a number of problems from the standpoint of practical administration. "[A] page of history," US Supreme Court Justice Oliver Wendell Holmes once observed, "is worth a volume of logic." ${ }^{10}$ If history, in the form of the American states' experience with the "unitary business" principle is any guide, the use of economic criteria to define the consolidated group is a recipe for uncertainty and inconsistency in the determination of the consolidated group. Although the US Supreme Court has attempted to delineate the unitary business principle in broad strokes over the course of the past century, the Court, recognizing that states have great latitude in the tax area, itself has acknowledged that "the unitary business concept ... is not, so to speak, unitary: there are variations on the theme, and any number of them are logically consistent with the underlying principles motivating the approach." 11 As a consequence, the decisions of the US Supreme Court - not to mention the scores of decisions emanating from state courts-"leave much room for controversy and confusion and little in the way of precise guides"12 to taxpayers and taxing authorities 
as to the scope of the consolidated (or "combined") group. The EU Member States could, of course, reduce uncertainty and inconsistency by formulating a single statutory standard. Even so, the concept of a unitary business, while compelling in principle, may be difficult to codify and implement successfully.

The difficulties of defining a consolidated group on the basis of economic interrelationships naturally lead to the recommendation of an approach to the group based simply on formal legal ownership. Such a test for consolidation would be relatively certain and thus easy to comply with and administer, and it would avoid the problematic fact-sensitive inquiries required by definition of a group based on economic criteria. There are two principal weaknesses in such an approach, however. First, as in the analogous case of apportioning what is arguably "nonbusiness income," it could lead to misattribution of income, because the income from affiliated — but economically unrelated — enterprises would be sourced by reference to consolidated apportionment factors that would not have contributed to the production of the income in question. Second, a definition of the consolidated apportionable tax base predicated solely on legal control could lead to manipulation by the careful adjustment of ownership interests in other corporations to minimize tax burdens, depending on whether consolidation or separate company reporting was more advantageous or disadvantageous from a tax standpoint. ${ }^{13}$

If the consolidated group includes less-than-100-percent-owned affiliates, one may raise the question whether all the income of such affiliates should be included in the apportionable tax base or only the proportionate share of income reflecting the consolidated group's ownership percentage in the affiliate. Under US state practice, once it is determined that an affiliate is includible in the combined group, all of its income (and all of its factors) typically are included in the base and the apportionment formula. (Hellerstein and Hellerstein, 1998, - 8.11). One might well argue, however, that it would be more appropriate to include only the pro rata share of the affiliate's income and factors in the base and formula (as it typically done with corporate investments in pass-through entities, such as partnerships and limited liability companies). (Hellerstein and Hellerstein, 1998, \ 9.15[6].) Although there is a plausible case for adopting either approach, we favor the former because of its greater administrative simplicity and because it is not likely to lead to distortion in the sourcing of income if the factors are properly constructed.

We have no magic wand to resolve the tension between a group definition that is conceptually attractive, but administratively cumbersome, and one that is administratively attractive but could lead to manipulation of ownership interests to minimize tax liability. One could, however, introduce anti-tax abuse safeguards into a group definition based on legal ownership that might mitigate this issue. (For example, the constructive stock ownership rules embodied in the Internal Revenue Code for purposes of denying losses among related parties (IRC $\S \S 267$ ) and in connection with various corporate transactions (IRC $\S 318$ ) would restrain the ability of economically related parties to manipulate their ownership interests to achieve tax benefits.) In addition, one might impose certain objective and easily admininistrable indicia of economic integration as a condition of consolidated filing (e.g., a percentage of revenues derived from related-party transactions). Finally, it may be possible to design a formula for the entire consolidated group that is both responsive to the underlying rationale for apportionment and is simple to administer. Based on all of 
these considerations, we give our nod to a legal, rather than an economic, definition of the consolidated group.

\subsection{Worldwide or Water's Edge?}

Twenty years ago the most famous—or infamous, in the eyes of many Europeans-attribute of unitary taxation of corporate income by some US states was worldwide combinationthe consolidation of the activities of related entities deemed to be engaged in a unitary business, no matter where such activities occurred and no matter where the entities or their parents were resident (see Weiner, 1996; 2001). Partly in response to the outrage expressed by Member States of the EU, the states abandoned worldwide combination and retreated to a "water's edge" definition of a combined (or consolidated) group limited to US domestic corporations, certain tax haven corporations, and foreign corporations that exceed a threshold of business activity in the US (Hellerstein and Hellerstein, 1998, ฯ 8.17).

The Commission's proposal would limit group taxation to income earned in the EU (Commission of the European Communities, 2002, pp. 482-486, 498). This seems entirely appropriate, for reasons known only too well in Europe, including international differences in accounting standards, the need to convert documents prepared in other languages, differences in the productivity of factors of production in various countries, and perverse effects of changes in exchange rates-issues that still exist within the EU, but are not nearly as important as between Member States and other nations. Perhaps most important, though not relevant in the state case, is the need for need for Member States to abandon the OECD Model Treaty and renegotiate all tax treaties with non-members of the EU, which are based on SA/ALS. See also Commission of the European Communities (2002, pp. 482-486), Lodin and Gammie (2001, pp. 84-102) and McLure (2002).

\subsection{Treatment of Income from Nonconsolidated Affiliates}

One question that must be considered in designing a CCBT regime is how to treat nonconsolidated affiliates. ${ }^{14}$ This involves two distinct questions: the division of income between consolidated and nonconsolidated affiliates and the treatment of dividends that consolidated affiliates receive from nonconsolidated affiliates. Perhaps the first issue that needs to be addressed is why the particular affiliate is not consolidated and whether that reason makes any difference for the purpose at hand. There are at least three possible classes of affiliates that would be excluded from the consolidated group: non-EU affiliates; EU affiliates from Member States that do not participate in the CCBT regime; and EU affiliates excluded from the consolidated group under the substantive rules of the CCBT regime itself (e.g., if the CCBT adopted a unitary approach to consolidation or excluded certain industry groups from consolidation). In our view, the reason why an affiliate is excluded from the CCBT group should not matter. In all instances, the excluded affiliate is effectively a "stranger" to the CCBT group, and we see no reason as a matter for principle why the CCBT should treat these "strangers" differently.

It seems generally to be assumed that the division of income between the members of the consolidated group and commonly-controlled members outside the group will continue to be 
governed by SA/ALS based on domestic law (under HST), existing bilateral treaties, or new protocols among participating Member States based on OECD guidelines for transactions with associated enterprises (Commission of the European Communities, 2002, pp. 482486, 498). In effect, the CCBT regime will need rules analogous to the "water's edge" rules developed by the American states that had previously required worldwide unitary combined reporting when they abandoned that approach in favor of the water's edge election. Separate accounting procedures employed by the states that do not require unitary combination seem woefully inadequate to prevent manipulation of transfer pricing.

US experience may also provide some useful "lessons" for CCBT designers looking for guidance with regard to the treatment of dividends received from nonconsolidated affiliates. With respect to dividends received from nonconsolidated domestic (US) corporations, the states generally follow the federal rule of excluding such dividends altogether when received from an 80-percent or more owned affiliate and excluding 70 percent of such dividends when received from other nonconsolidated domestic corporations. Under constitutional rules forbidding discrimination against foreign commerce, ${ }^{15}$ states are required to provide at least as favorable treatment to dividends received from foreign (non-US) nonconsolidated corporations. Under water's edge legislation, some states go even further by excluding an even greater percentage or all dividends received from foreign corporations from the state tax base. When dividends are included in the apportionable tax base, there has been controversy and litigation over the question whether the apportionment formula of the recipient should reflect the factors of the company paying the dividends.

In our view, it would be appropriate for a CCBT that uses FA to implement source-based taxation of EU-source income simply to exempt all income received from nonconsolidated affiliates, including dividends (see also McLure, 1986). This would make both administrative and conceptual sense. The debate over "factor representation" would be unnecessary if the states were to adopt this conceptually correct approach. As in any system that exempts foreign source income from tax, it might be necessary to adopt anti-abuse rules to prevent improper income shifting.

The Commission is silent on the question of whether there would be a residence-based overlay on top of the source-based tax system we have been discussing. We do not discuss this issue, which the US states do not face because they do not employ a residence/credit scheme for taxing corporate income. It seems, however, that if some Member States continue to employ the residence/credit system, their source-based definition of apportionable income should not include foreign-source income, which would be added to their apportioned share of the "water's edge" apportionable base, in order to derive a residence-based measure of income.

\section{The Apportionment Formula}

The third key element in a system of FA is, of course, the apportionment formula. This section provides a brief historical overview of US practice, examines theoretical underpinnings for various apportionment factors, and describes and appraises current US practice. Finally, it considers the possibility of using value added at origin to apportion income-an issue on which US experience sheds no direct light. 


\subsection{Historical Overview}

The states began early in the 20th century to impose corporate income taxes, and 17 did so by the end of the 1920s. While these taxes were initially based on separate accounting, pressure from business groups soon led to the use of formulary apportionment. However, apportionment formulas adopted by the various states were far from uniform. A committee of the National Tax Association (NTA) reported in 1922 that "the factors entering into different formulas and given more or less weight therein, would include tangible property, intangible property, receivables, sales, manufacturing costs, wages, salaries, purchases, etc." In an attempt to bring order to this chaotic situation, the NTA recommended that all states use a formula to divide the income of corporations involved in manufacturing and mercantile activities that would place equal weight on tangible property and "business," which it defined as the sum of wages, salaries, and materials plus receipts from sales. (NTA, 1922, pp. 199, 206) The states failed to adopt this recommendation, and in 1933 the NTA recommended the "Massachusetts formula," which placed equal weight on payroll, property, and sales, not so much because it was seen to be conceptually attractive but because "uniformity is preferable to scientific accuracy." States shifted toward this formula, which was enshrined in UDITPA in 1957 and in the Multistate Tax Compact (which incorporates UDITPA) in 1967, and by 1978 virtually all income-tax states used it. Since then, however, there has been a tendency to place greater (commonly double) weight on sales, and now more than half the states assign at least half the weight to sales and eight use only sales to apportion income. This is widely interpreted as an attempt to improve the competitive position of the taxing state, by shifting from apportionment factors that reflect the origin of sales (payroll and property) to one that reflects their destination (see, for example, Mazerov, 2001). Also, industry-specific formulas have been created to deal with the special situations of certain industries such as construction, transportation, financial institutions, professional sports, and broadcasting. For further discussion of historical developments, see Weiner $(1992,1994)$ and Hellerstein and Hellerstein (1998, ๆ 8.03-8.06).

\subsection{Theoretical Perspective}

This sub-section considers the theoretical underpinnings of various apportionment formulas and factors. It takes as given the objective of taxing income in the jurisdiction where it arises. It does not inquire whether or not achieving that objective would further policy objectives such as equity, economic neutrality, or benefit taxation. It does not consider the possibility of using value added to apportion income; Section 4.4 examines that issue.

4.2.1. Economic Analysis of Traditional Factors In this section we attempt to provide a theoretical foundation for thinking about the choice of standard apportionment factors. We do not mean to suggest that this approach should (or could) be implemented by looking at the nature of the income of individual taxpayers (see also the "synthesis" below).

Given the objective of taxing income where it originates, apportionment formulas should contain factors that reflect the geographic origin of income. In selecting apportionment factors to include in a standard formula, one may usefully differentiate between the normal 
return to equity capital and economic profits, as different factors may indicate the origin of the two types of income. (In theory one might make a further distinction between capital financed by debt and by equity, since company income is the return to the latter. Of course, it would be impossible to determine the source of financing of capital employed in a particular jurisdiction, and any attempt to do so would create opportunities for tax planning.)

Normal Return to Capital. Musgrave (1984) suggests that there are two ways to look at the division of normal profits: the supply-based and supply/demand-based views. She argues that in the supply-based view capital should be used to apportion income (because it is the return to capital that is under examination), and there is no room for a sales factor (because capital employed in market states would reflect the contribution those states make to income) or even a payroll factor; Mintz (1999) reaches the same conclusion and Sørensen (2004) emphasizes the locational distortions created by apportionment based on labor costs. Musgrave (1984, p. 241) notes, "for supply-based source rules, the factor inputs should be measured in a way that reflects their inclusion in the production function," and distinguishes two approaches to the measurement of capital, a "stock" approach and a "flow" approach. Whereas the former would be based on the current (depreciated) market value of assets, the latter would be based on economic depreciation and interest (the user cost of capital).

If production is characterized by fixed proportions or if production functions and relative prices of factors of production are the same in all taxing jurisdictions, it makes no difference from a theoretical point of view whether payroll or property is used to apportion income arising in a given industry, and the choice can be made on grounds of administrative efficiency. If factor proportions depend on the relative cost of productive factors and if labor costs (or the cost of capital), and thus optimal factor proportions, differ dramatically between taxing jurisdictions, the use of payrolls as a proxy for capital costs is likely to be unsatisfactory, even within a given industry. More important, factor proportions are not likely to be similar across all industries, elements of which might be found within a single consolidated group, especially if the definition of groups is based on common ownership. This creates the presumption that labor may not be a good proxy for capital costs and reinforces the conclusion that there is little theoretical foundation for basing apportionment on payroll.

Some, especially in developing countries, argue that the present rules for the division of income between nations accords too little weight to the market. Musgrave (1984) suggests that a destination-based sales factor (but not a payroll factor) might be included along with capital under the supply/demand-based view of where normal profits arise. (In that case it presumably makes sense to include sales to business in the sales factor, even though such sales would not be subject to a conceptually proper retail sales tax and tax is eliminated by input credits under a VAT. An origin-based sales factor would attribute profits to the place of production, rather than to market jurisdictions. Also, it would implicitly include payments to labor, as well as the return to capital. See also the discussion of apportionment based on value added in Section 4.4.) While it seems likely that most economists would favor the supply-based view, there is no scientific way to choose between the two views or 
to know the proper weight to assign to property and sales under the supply/demand view. If a destination-based measure of sales is employed, as in the US, the extreme solution of "sales-only apportionment" is likely to violate international trade rules; see McLure and Hellerstein (2002).

Economic Profits. The theoretically correct formula for the apportionment of economic profits depends on the source of the profits. In the case of locational rents associated with production, origin-based factors such as property would be most appropriate, as in the supply-based view of the apportionment of normal profits. But in this case the value of certain types of assets (which reflects profits), rather than their cost or even the user cost of capital (which do not), would provide a more accurate measure of the contribution of location-specific assets to the creation of profits. Thus, for example, the value of natural resources should be included in the value of property used to apportion resource rents (or, better yet, a concept analogous to the user cost of capital that reflects resource and other rents could be employed generally).

Jurisdictions where intellectual property such as patents (e.g., of pharmaceuticals) and software is developed have a strong claim to profits associated with those intangible assets. To be consistent with the current treatment of tangible assets in the US, the cost of intangible assets could be calculated by capitalizing costs, for example, of R\&D or software development. But, as in the case of locational rents, costs of creating intangible assets do not adequately capture geographic contributions to economic profits.

A destination (demand)-based factor such as sales would serve better to apportion profits linked to markets, such as those resulting from tariff protection and advertising. (Note that, unlike the cost of capital, sales automatically reflect profits; they do not, however, indicate whether profits are attributable to production or market activities.)

Synthesis. It does not seem that there is a good case for basing apportionment on costs of labor; after all, corporate income is a return to capital, not labor. Beyond that, any effort to put this theoretical reasoning together leads inexorably to the conclusion that "it depends," an answer that is profoundly unsatisfactory for those seeking practical guidance for the design of statutory apportionment formulas. One cannot, in the real world, make formulary apportionment depend on the distinction between normal and economic profits and the source of the latter. (It is worth noting that this is precisely the type of detailed economic analysis of the activities of individual taxpayers that is anticipated in the "transactional profit methods" enshrined in the OECD Transfer Pricing Guidelines, which formulary apportionment attempts to avoid.) Moreover, theory does not provide adequate guidance on the weight to place on sales. Perhaps the best that one can do is to conclude, as the NTA committee did 80 years ago, that "All methods of apportionment ... are arbitrarythe cutting of the Gordian knot. ... [T] here probably are a number of different rules, all of which may work substantial justice... [T] he only right rule ... is a rule on which the several states can and will get together as a matter of comity." The EU Commission (2002, p. 502) has, perhaps somewhat grudgingly, acknowledged this viewpoint, "Although it has been argued that the precise factors in the formula are of less importance than the fact that they should be standardised across those administrations applying them, the choice of factors remains important." 
4.2.2. Micro- or Macro Factors? Using apportionment factors that are specific to particular taxpayers ("micro" factors) inevitably affects incentives regarding the location of the economic activities that comprise the factors (e.g., payroll, property, and sales), unless tax rates are identical. One can perhaps see this most easily by recognizing that an income tax based on taxpayer-specific FA is economically equivalent to a tax on the taxpayer's apportionment factors; see McLure (1980). These effects can be avoided by using "macro" apportionment factors based on industry averages. The EU Commission has said (2002, p. 505), in describing this approach, "Instead of seeking enterprise-specific allocation keys, the computed EU tax base would be allocated in proportion to economic data at the level of the Member State," see also Mintz (1999, p. 407). But the use of macro factors can result in attribution of income to Member States that bears little or no relation to where it is earned - for example to a Member State where the taxpayer conducts little or no business. ${ }^{16}$ (For that reason — and because income tax liability must be based on the attributes of the taxpayer-use of macro factors would not be constitutional in the US.) The Commission seems to be aware that using macro-level apportionment factors is problematical, as it has acknowledged (2002, p. 505), "[A]llocation at such a macro level might really only be appropriate if it were the tax itself which was being allocated..."

\subsection{US Practice: Description and Analysis}

As noted above, the US states employ payroll, property, and sales, weighted in ways that vary from state to state, to apportion income in the absence of a special industry-specific formula. The two factors that have most appeal from a theoretical perspective, property and (with substantially less appeal) sales, are plagued by the most serious practical problems. We focus on them.

4.3.1. The Payroll Factor While not attractive from a theoretical point of view, use of a payroll factor may have administrative advantages. Payroll may be the easiest factor to measure. Among potential problems with the payroll factor are the treatment of fringe benefits and payments to independent contractors. If payroll is to appear in the apportionment formula, both should be included in the payroll factor. (Inclusion of payments to independent contractors is analogous to inclusion of leased property in the property factor, described below.)

In the US the payroll factor follows the federal definition of payroll for unemployment tax purposes. There is presently no comparable readily available counterpart in the EU.

4.3.2. The Property Factor The standard property factor in the US considers only tangible property; that is, it excludes intangible property such as intellectual property, stocks, and bonds. (Intangible assets are included in formulas for specific industries such as financial services.) The value of tangible property is based on historical cost rather than actual value, with no adjustment for either depreciation or inflation (or for replacement cost); only when an asset is retired is it dropped from the property factor. Leased assets are included by multiplying annual lease payments by eight.

The problems with the property factor are manifest from this description. First, it is not appropriate to ignore intangible assets, which are the "crown jewels" of the modern 
corporation; see McLure (1997). (Wholly apart from the implications for the division of the tax base, McLure (2000b), provides an example in which ignoring intangible assets can significantly distort decisions on the location of tangible assets.) Yet treating them properly is far from straightforward. A "one-size-fits all" approach-for company stock (which should be omitted, assuming dividends are exempt), for intellectual property (discussed above), and for debt obligations (which have no obvious economic situs) — is not appropriate. Determining the fraction of the cost or value of intangible assets such as intellectual property or marketing assets that should be attributed to a particular location involves transfer pricing problems similar to those under SA/ALS.

Second, the cost of assets provides a poor approximation of both their value and the user cost of capital; its use to apportion income results in systematic overstatement of the contribution of long-lived assets, compared to apportionment based on the user cost of capital. Third, equally valuable assets will be treated differently if they have different historical costs. Fourth, the contribution of old assets is overstated by the failure to take account of depreciation. Fifth, the contribution of old assets would be understated following an inflationary period. Sixth, the use of a single multiplier to capitalize payments on leases of different lengths is not appropriate. Seventh, because lease payments are likely to approximate the user cost of capital, including depreciation and expected inflation, their treatment is not commensurate with that of other assets.

Finally, if some affiliates are not included in the consolidated group, because of the definition of the group, because CBT/FA is not used throughout the EU (as is likely under the CCBT and HST proposals), or because the affiliates are located outside the EU, it would be possible to manipulate transfer prices on transactions between affiliates to misstate the allocation of property between Member States that participate in the group subject to CBT/FA. Large investment projects would be relatively easy for tax authorities to identify and monitor, but difficult to value, because of their uniqueness.

In short, the US property factor in its traditional configuration is fraught with conceptual problems that are inherently difficult to overcome, although from a practical standpoint it has been relatively easy to administer.

4.3.3. The Sales Factor In the US the sales factor is not limited to sales of goods; most states, pursuant to UDITPA or similar statutes, define it as all gross receipts not allocated as "nonbusiness income" to a specific state. Thus it includes, inter alia, receipts from the provision of services, rentals, and royalties; whether it includes gross receipts from sales of financial assets, or only net sales, is often subject to controversy, special legislation and regulations, and litigation. Sales of tangible property are generally attributed to the state of destination. By comparison, sales other than sales of tangible personal property (including receipts from services and from sales of intangible property) are commonly attributed to the state where income-producing activities are performed (either on an all-or-nothing basis to the state where the greatest fraction of cost of performance occurs or in proportion to such costs), but some states also attribute these sales to the state of the market for such services or intangibles (destination). Many states employ a "throwback" provision that attributes to the state of origin sales that are made to a state that lacks jurisdiction to tax the income of the vendor or to the federal government. 
Of the three principal factors employed in the US, the sales factor has generated the most practical controversy. Controversial issues include determination of the state of destination of tangible personal property (intermediate or final); application of the "throwback" rule; application of the sales destination test to "drop shipment" sales; application of the sales destination test or throwback rule to sales made by a member of a combined group without nexus into a state where another member of the group has nexus; application of the cost-of-performance test to various services; and attribution of receipts from intangibles (including financial assets); see Hellerstein and Hellerstein (1998, $\uparrow$ 9.18). Most of these issues could be addressed in carefully drafted legislation. Worth particular mention are the difficulty of knowing the destination of some sales of intangibles delivered over the Internet and the lack of rationale for throwback. "Throwout"- exclusion from the apportionment formula of sales to the federal government and to states and to foreign nations that do not have jurisdiction to tax - would be more sensible, since such sales should simply be ignored, rather than attributed to the state of origin. Sales to states or foreign nations that do not tax income, but where the taxpayer has nexus, should be excluded from the numerator of the sales factors of all income-tax states and nations, but not from the denominator.

If some affiliates were not included in the consolidated group, for reasons mentioned earlier, it might be possible to manipulate transfer prices to lodge sales in low-tax jurisdictions. Because of the greater quantity of transactions, this would be more difficult to monitor than the manipulation of the property factor mentioned above. While similar in nature to transfer pricing problems under the present system, this problem would be quantitatively less important in a system based on formulary apportionment. To see this suppose that $€ 100$ of sales (and thus of income) is shifted from a Member State with a tax rate of 40 percent to one with a rate of 10 percent. Under the present system this would result in a tax saving of $€ 30$. Initially suppose that sales is the only apportionment factor in an FA system. The change in combined tax liability resulting from the shift can be expressed as $\Delta T=100 \times 0.30 \times \Pi / \mathrm{S}$, where $\Pi$ represents the taxpayer's apportionable income and $\Pi / S$ is the ratio of apportionable income to sales, a figure that is typically well below unity. The tax saving under FA, compared to that under the present system, is only $\Pi / \mathrm{S}$ as large. If sales is only one of three equally weighted factors, the tax saving from manipulation of the sales factor would be reduced by an additional $2 / 3$.

\subsection{The Value-Added Option: Cutting the Gordian Knot?}

The European Commission (2002, pp. 504-505), apparently following a suggestion by Lodin, Gammie and IBFD (2001, pp. 47-50), has raised the possibility of using value added at origin to apportion income within the EU. Since no country currently uses this approach, it deserves careful attention. We begin with some observations on conceptual and theoretical issues and then discuss what may be the Achilles heel of this proposal, transfer prices for sales crossing borders within the EU. Finally, we investigate the possibility of using value added at destination (or revenues under the extant destination-based VAT) to apportion profits. We emphasize that the conclusions presented here are tentative, as this issue deserves more attention than time and space in this article allow. 
4.4.1. Conceptual/Theoretical Issues Value added at origin has notable practical advantages over the use of payroll and property as distinct apportionment factors, especially if one wishes to include labor costs in an apportionment formula. First, the weights implicitly assigned to the two factors are chosen by market forces, rather than being totally arbitrary. Second, there is no need to calculate the cost, value, or user cost of capital. This is especially important in the case of intangible assets. Third, it appears that value added could be used to apportion income in all industries, obviating the need for special formulas. (Special rules for the calculation of value added may be required for companies making supplies that are VAT exempt; for example, an addition-based measure of value added may be required for financial institutions and insurance companies.) If affiliates involved in different industries are part of a single group subject to combined or consolidated reporting, this could be a quite important advantage. Fourth, taxpayers in all Member States already calculate VAT liability based on an essentially uniform standard - albeit one that differs in important ways, to be noted below, from the measure of value added that might be used to apportion income. The fact that the value added tax is based on cash accounting, whereas the income tax typically is based on accrual, does not seem to be a serious fault, since an approximate measure of business activities in various Member States is the objective; it seems that this difference would not matter much for most companies in most years.

Part of the EU Commission's argument for basing apportionment on value added, "the advantage of additionally including labour costs," is unconvincing. We saw in Section 4.2 that the primary objective of formulary apportionment should probably be to reflect the contribution of capital, including intellectual property, to the earning of income and that there is little theoretical reason to include the cost of labor in an apportionment formula, no matter what its conceptual foundation (supply, supply/demand, production-based location rents, intellectual property, or marketing profits). Thus we see the inclusion of labor costs in value added as a disadvantage, rather than an advantage from this perspective. Jacques Sasseville of the OECD, in conversation, has suggested deducting labor costs in creating an apportionment factor based on value added. The remainder of the present discussion thus concentrates on the use of value added minus labor costs to apportion income.

Provided transfer pricing problems can be handled satisfactorily, apportionment based on value added minus labor costs may generally do well in implementing the source-based view of normal profits and in attributing production-based location rents, economic profits resulting from intellectual property, and marketing profits to the proper jurisdictions. It might allow the EU to sidestep many of the knotty issues that have bedeviled FA in the US, including the need for different formulas for different industries, the choice between grouping based on legal ownership and economic considerations, and the distinction between business and non-business income.

In some sectors "profits" may really be the return to entrepreneurial effort, or even compensation for labor; in those instances the fit between profits and this apportionment factor may not be so good. Also, deduction of labor costs from value added may leave a negative number. It would, of course, make no sense to base apportionment of profits on this residual. But one would expect that profits would also generally be negative in such cases.

It is also true that one would need a precise definition of the labor costs that are being deducted from value added, but this task does not seem insuperable, as suggested by the 
above discussion of the payroll factor. More troubling is the fact that payments to labor constitute a substantial fraction of the value added in the financial sector, but would be ignored under the proposal under consideration. Finally, it would be necessary to calculate value added (perhaps minus labor costs) on a group basis, but that seems to be a simple matter of addition.

Our conclusion is that, on balance, apportionment based on value added minus labor costs has both theoretical and practical advantages, relative to traditional apportionment factors. This leaves a crucial question: whether transfer pricing is a "show stopper."

4.4.2. Transfer Pricing: The Black Cloud Because they are based on the credit method, European value-added taxes (VATs) do not involve the calculation of value added. Rather, to calculate their liability for VAT, registered traders deduct tax paid on purchases from tax on sales. It would, however, seem relatively simple for registered traders to construct a measure of value added by subtracting taxable purchases from taxable sales, as under a subtraction-based VAT. ${ }^{17}$ (We do not consider the situation of non-registered traders, which, except for such obvious cases as finance and insurance, seem unlikely to operate in more than one Member State.) Once the basic value added measure has been constructed, the consumption/destination-based measure implicit in the present system would be converted to an income/origin-based measure by making two adjustments: (a) exports would be added and imports would be subtracted and (b) capital investment would be added and depreciation allowances would be subtracted. (The analogous adjustment for inventories does not seem to be anticipated.) In the Sasseville approach there would be a further adjustment for labor costs.

This description immediately exposes the most important potential problem with apportionment based on value added at origin: the possibility of manipulation of transfer prices on imports and exports. (Lodin, Gammie and IBFD, 2001, pp. 49, 71-73, make a similar point.) Whereas there is no incentive for registered traders operating in several Member States to manipulate transfer prices under a destination-based VAT, such incentives would exist under an origin-based VAT and thus under an apportionment system based on value added at origin. Nor would the existence of the VAT act as a brake on this form of abuse, as manipulation of the value of exports and imports by registered traders generally has no ultimate effect on VAT liabilities. Particularly important is the need for accurate transfer prices for intangible assets such as intellectual property, without which value added can be shifted between Member States in order to minimize taxes (for example, from high-tax states where $R \& D$ occurs to low-tax states where production based on the intangible assets occurs). The inability of SA/ALS to deal with this problem satisfactorily is, of course, one of the key reasons formulary apportionment might be favored over that system. Moreover, the need to monitor transfer prices for imports and exports runs directly counter to one of the key objectives of the Commission, eliminating the need for VAT taxpayers to know the destination of sales within the EU (on this, see Keen and Smith, 2000. The proposal in McLure, 2000a, relies on such a distinction).

The deduction of labor costs from value added would magnify the incentive to manipulate transfer prices. (Suppose that imports and exports, correctly valued, are both $€ 10$, value added is $€ 100$, whether measured on the origin or destination basis, labor costs are $€ 70$, and value added minus labor costs is $€ 30$. A 30 percent overstatement of imports (that 
is, an overstatement of $€ 3$ ) would cause value added at origin to be understated by only 3 percent, but it would cause value added minus labor costs to be understated by 10 percent.) Sasseville, in commenting on an earlier draft of this paper, has indicated, "the issue of transfer pricing would be enough for me to suggest not to deduct labour costs from valueadded. This is purely based on administrative considerations: since labour costs may be the biggest component of the value-added and since they are not prone to transfer pricing manipulation, I believe that the only way that a value-added apportionment can result in a significant reduction of the current transfer pricing problems (and therefore be arguably better than the arm's length principle) would be if labour costs were included."

4.4.3. Apportionment Based on Value Added at Destination The transfer pricing problems just discussed and the fact that all Member States of the EU employ a destination-based VAT have led some commentators on an earlier draft of this article to inquire about the use of a destination-based measure of value added to apportion profits. This approach seems to encounter overwhelming problems of implementation, as well as theoretical deficiencies.

Whereas value added at origin - the difference between sales, including exports, and purchases, including imports-is a concept that has meaning as a measure of the output of a given company, value-added at destination does not have the same conceptual appeal. Apportionment based on value-added at destination would presumably have an objective similar to that of a conventional destination-based sales factor, to allocate profits to jurisdictions where sales are destined. But neither the credit/invoice method nor the subtraction method of implementing a VAT automatically provides the information required to make this allocation. The basic problem is that, in the case of cross-border trade, the vendor whose profits are to be apportioned is located in one jurisdiction, but value added is implicitly attributed to another (the jurisdiction where final consumption occurs) and VAT is remitted by a different vendor.

Consider how a VAT operates with regard to cross-border trade. Under the invoice/credit method employed in the EU, exports are zero-rated in the nation of origin. (They would be deductible from total sales under a subtraction-method VAT.) This implies that a vendor that exports all its production would have no VAT liability (no taxable value added under the subtraction method) and thus no basis for apportioning profits. (Indeed, the exporter may be eligible for a refund of input tax.) Results are less extreme if not all production is exported, but the fact remains that sales at destination are not taxable to the vendor and would not enter the vendor's calculation of value added used to apportion profits, as they would under a conventional destination-based sales factor. Thus implementation of a destination-based measure of value added would require vendors to record the destination of sales, creating both compliance and administrative problems. (As noted earlier, avoiding the need for such records is one of the long-standing goals of the Commission.) Worse, recall that the proximate objective is to determine the destination of value added, not sales. Such a determination would require the attribution of overhead and other costs to sales made to various destinations, creating even more compliance and administrative problems and opening the way for manipulation of the attribution of value added.

Imports are the mirror image of the problem. VAT is ultimately collected only by the jurisdiction where sales are made to purchasers who are not eligible to take credit for tax 
paid on purchases (mostly consumers). The vendor who remits VAT is generally not the one who earned the profits that are to be allocated.

\subsection{Concluding Remarks on the Choice of the Apportionment Formula}

The most important lesson from examination of US experience with apportionment formulas is "don't do what we do." The US approach lacks satisfactory conceptual and theoretical foundations and, as implemented, suffers from serious practical problems. While some of the practical problems are remediable, the conceptual and theoretical deficiencies are not. Given this, value-added at origin, perhaps adjusted to exclude the contribution of labor, may be the most satisfactory—or least unsatisfactory—apportionment factor. This suggests that this option should be subjected to greater scrutiny, in order to assess its practicality, identify potential problems, and appraise their importance. Apportionment based on value added at destination seems to be totally unworkable.

\section{Tax Administration}

One might have thought that there are significant lessons for the EU with regard to crossborder tax administration, since the states cooperate in the administration of UDITPA through the Multistate Tax Commission (MTC). (See Hellerstein and McLure, 2004, for a more detailed discussion of the MTC.) In fact, there is less than meets the eye in this domain. Despite some cooperation under the auspices of the MTC, both with regards to developing uniform regulations under UDITPA and undertaking multistate, joint audits of taxpayers, the fact remains that the MTC performs only an advisory function. States may individually adopt the MTC regulations if they so choose, but are under no obligation to do so. Similarly, audits are conducted on behalf of states only when the individual states sign on to such audits, which they do on a case-by-case basis; even then, the states are not bound by the recommendations of such audits. If one is looking for a more robust model of interstate cooperation, it may well be the Streamlined Sales Tax Project, which is designed to simplify and harmonize the states' sales and use tax laws and administration. But that is a topic for another day. See Streamlined Sales Tax Project (2003).

\section{Summary Appraisal}

"Don't do what we do" also summarizes our overall appraisal of what the EU can learn from the US state experience with taxation based on formulary apportionment. ${ }^{18}$ The EU cannot do the one thing the US does relatively well, using the federal definition of taxable income as a starting point. It probably should not follow the US lead in distinguishing between "business" and "non-business" income or in basing consolidation on the concept of a unitary business; both of these practices can be explained in large part by uniquely American constitutional constraints on what the states can do. Of the three factors used to apportion income, only property has much conceptual appeal, and it suffers from serious measurement problems, only some of which could easily be avoided. Sales at destination, which states are relying on increasingly to apportion income, suffers from both conceptual 
and measurement problems. Apportionment based on value added at origin, perhaps with deduction of labor costs, which could not easily be implemented in the US, seems a far better alternative for the EU, especially if no distinction is made between "business" and "non-business" income and if consolidation is based solely on ownership. It may, however, be doomed by transfer pricing problems.

\section{Acknowledgment}

The authors, who are solely responsible for the contents of this paper, acknowledge comments Richard Bird, Sijbren Cnossen, Clemens Fuest, Silvia Giannini, Sven-Olof Lodin, Jack Mintz, Peggy Musgrave, Julie Roin, Jacques Sasseville, Joann Weiner, and an anonymous referee made on an earlier draft.

\section{Notes}

1. Under the other proposal, for a European Union Company Income Tax, the EU would levy the corporation income tax, revenues from which might be shared with Member States. Like HTB, it is generally considered to be politically unacceptable.

2. UDITPA was drafted in the late 1950 s by the National Conference of Commissioners on Uniform State Laws to serve a model for states to follow in apportioning and allocating income. UDITPA is concerned only with division of income among the states; it does not address tax base issues. Roughly half the states with corporate income taxes have adopted UDITPA, although there are individual state variations from the model act, particularly regarding the weighting of the apportionment factors. Most other states have division-ofincome regimes that strongly resemble UDITPA. (For further discussion of UDITPA and the context in which it operates, see Hellerstein and McLure, 2004.)

3. Container Corp. of America v. Franchise Tax Board, 463 U.S. 159, 192 (1983).

4. See Tenneco West, Inc. v. Franchise Tax Board, 234 Cal. App. 3d 1510, 286 Cal. Rptr. 354 (4th Dist. 1991).

5. Mobil Oil Corp. v. Commissioner of Taxes, 445 U.S. 425, 439 (1980).

6. Container Corp. of America v. Franchise Tax Board, 463 U.S. 159, 183 (1983).

7. Id.

8. Id. at 178 n. 17.

9. While the US Federal Government does permit commonly-controlled entities engaged in wholly unrelated businesses to file a consolidated return, thereby allowing the offsetting of profits and losses among affiliated but economically discrete corporations, it is important to recognize that the consolidated group is limited to US domestic corporations, 100 percent of whose income is subject to tax on a residence basis. This is a significantly different situation from that confronting the EU (and the American states), in which many of the corporations whose income (or losses) would be subject to consolidation would be subject to tax in the Member State only on the basis of source.

10. New York Trust v. Eisner, 256 U.S. 345, 349 (1921).

11. Container Corp. of America v. Franchise Tax Board, 463 U.S. 159, 167 (1983).

12. Northwestern States Portland Cement Co. v. Minnesota, 358 U.S. 450, 458 (1959).

13. Since common ownership would be a requirement even under an economic approach to the definition of the consolidated group, such a problem is not unique to a definition of a group tied solely to legal control. Nevertheless, the problem is less pronounced in the former context because economic unity is a precondition to the requirement that companies file on a consolidated basis.

14. Although this question may more properly be viewed as a "base" issue than a "group" issue, we have reserved our treatment of the issue to the end of the base/group discussion because it is difficult to consider the question without first having determined the definition of the consolidated group.

15. Kraft General Foods, Inc. v. Iowa Department of Revenue, 505 U.S. 71 (1992).

16. More generally, the use of macro factors can interact with nexus rules to produce unacceptable results. If the same set of macro factors is used for all companies in a given industry, without regard to whether they have 
nexus in particular Member States, a taxpayer could have tax liability to a Member State where it conducts no business. On the other hand, if the apportionment factor applicable to a particular taxpayer is tailored to reflect only the macro factors for Member States where the taxpayer has nexus, the result could be either an opportunity to manipulate nexus to shift income to low-tax Member States or a "toll charge" for expansion into additional high-tax Member States that would seem to contravene the establishment clause in the EU Treaty.

17. Some, having heard that two US states levy value added taxes, might wonder whether those taxes provide the key to apportionment based on value added. The operation of these taxes dictates a negative answer. Michigan utilizes the addition method to calculate value added, which it apportions based on a three-factor formula similar to UDITPA's (but with greater weight on sales). New Hampshire's "Business Enterprise Tax" is imposed on the sum of compensation, interest, and dividends paid by a company engaged in business in the state. Compensation is apportioned by a factor that resembles UDITPA's payroll factor; interest by one that resembles UDITPA's property factor; and dividends by a three-factor formula resembling the UDITPA formula. Thus in neither case would we avoid the inadequacies of the UDITPA factors that motivated the inquiry.

18. Lannoo and Levin (2002) conclude, "The US system ... is not an example of the best functioning and most uncontroversial system available. Canada is probably a more appropriate example." Note, however, that the Canadian system has an important flaw: it does not allow consolidation. For a contrary view on this issue, see Mintz (2004).

\section{References}

Cnossen, S. (2001). "Tax Policy in the European Union: A Review of Issues and Options," Finanzarchiv 58, $466-558$.

Commission of the European Communities. (2001). "Towards an Internal Market without Tax Obstacles: A Strategy for Providing Companies with a Consolidated Corporate Tax Base for Their EU-Wide Activities." A Communication from the Commission to the Council, the European Parliament, and the Economic and Social Committee, $\operatorname{COM}(2001) 582$ final.

Commission of the European Communities. (2002). "Company Taxation in the Internal Market." Commission Staff Working Paper, $\operatorname{COM(2001)~} 582$ final. Luxembourg: Office for Official Publications of the European Communities. (Originally published as SEC (2001) 1681, 23 October 2001). http://europa.eu.int/comm/ taxation_customs/taxation/company_tax/working_paper.htm.

Commission of the European Communities, Directorate General Taxation and Customs Union. (2003). "The Application of International Accounting Standards (IAS) in 2005 and the Implications for the Introduction of a Consolidated Tax Base for Companies' EU-Wide Activities.” Available at http://europa.eu.int/comm/ taxation_customs/taxation/consultations/iaspaper06feb2.pdf.

Devereaux, M. P. (2004). "Debating Proposed Reforms of the Taxation of Corporate Income in the European Union," International Tax and Public Finance 11(1), 71-89.

Gammie, M., C. M. Radaelli and A. Klemm. (2001). "EU Corporate Tax Reform: Report of a CEPS Task Force," Centre for European Policy Studies.

Gordon, R. and J. D. Wilson. (1986). "An Examination of Multi-Jurisdictional Corporate Income Taxation Under Formula Apportionment,” Econometrica 54, 1357-1373.

Hellerstein, W. (1993). "State Taxation of Corporate Income from Intangibles: Allied Signal and Beyond," Tax Law Review 48, 739-879.

Hellerstein, W. (2001). "The Business/Non-Business Income Distinction and the Case for Its Abolition," State Tax Notes 21, 725-739.

Hellerstein, J. R. and W. Hellerstein. (1998). State Taxation, 3rd ed. Boston: Warren, Gorham, and Lamont.

Hellerstein, J. R. and W. Hellerstein. (2001). State and Local Taxation, 7th ed. St. Paul, Minn: West Group.

Hellerstein, W. and C. E. McLure, Jr. (2004). "Lost in Translation: Contextual Considerations in Evaluating the Relevance of US Experience for the European Commission's Company Taxation Proposals," forthcoming in Bulletin for International Fiscal Documentation.

Keen, M. and S. Smith. (2000). "Viva VIVAT!” International Tax and Public Finance 7, 741-751. 
Lannoo, K. and M. Levin. (2002). "An EU Company without an EU Tax? A Corporate Tax Action Plan for Advancing the Lisbon Process." A Research Report by the Centre for European Policy Studies (CEPS). Available at http://europa.eu.int/comm/taxation_customs/taxation/company_tax/docs/corporate_taxation.pdf.

Lodin, S. O. and M. Gammie and IBFD Research Department. (2001). Home State Taxation and Tax Treaty Aspects. Amsterdam: International Bureau for Fiscal Documentation.

Mazerov, M. (2001). "The Single-Sales-Factor Formula: A Boon to Economic Development or a Costly Giveaway?" State Tax Notes 20, 1775-1817.

McLure, C. E., Jr. (1980). “The State Corporate Income Tax: Lambs in Wolves' Clothing.” In H. J. Aaron and M. J. Boskin (eds.), The Economics of Taxation. Washington: Brookings Institution.

McLure, C. E., Jr. (1986). "State Taxation of Foreign-Source Dividends: Starting from First Principles," Tax Notes $30,475-489$.

McLure, C. E., Jr. (1997). "Preliminary Thoughts on Federal Use of Formula Apportionment in the Taxation of Income from Intangibles," Tax Notes International 14, 859-871.

McLure, C. E., Jr. ( 2000a). "Implementing Subnational VATs on Internal Trade: The Compensating VAT (CVAT)," International Tax and Public Finance 7, 723-740.

McLure, C. E., Jr. (2000b). “Implementing State Corporate Income Taxes in the Digital Age,” National Tax Journal $53,1287-1305$.

McLure, C. E., Jr. (2002). "Replacing Separate Entity Accounting and the Arm's Length Standard with Formulary Apportionment," Bulletin for International Fiscal Documentation 56, 586-599.

McLure, C. E., Jr. and W. Hellerstein. (2002). "Does Sales-Only Apportionment of Corporate Income Violate International Trade Rules?" Tax Notes 96, 1513-1520; State Tax Notes 25, 779-786; Tax Notes International 27, 1315-1323; CES/ifo Forum 3, 23-30.

McLure, C. E., Jr. and J. M. Weiner. (2000). "Deciding Whether the European Union Should Adopt Formula Apportionment of Company Income." In S. Cnossen (ed.), Taxing Capital Income in the European Union: Issues and Options for Reform. Oxford: Oxford Univ. Press.

Mintz, J. M. (1999). "Globalization of the Corporate Income Tax: The Role of Allocation," Finanzarchiv 56, $389-423$.

Mintz, J. (2004). "Corporate Tax Harmonization in Europe: It's All About Compliance," International Tax and Public Finance 11(2), 221-234.

Mintz, J. and J. M. Weiner. (2003). "Exploring Formula Apportionment for the European Union." Presented at a Conference on "Tax Policy in the European Union," held at the Research Center for Economic Policy, Erasmus University, Rotterdam, 17-19 Oct. 2001, in International Tax and Public Finance, 10(6), 695-711.

Musgrave, P. B. (1984). "Principles for Dividing the State Corporate Tax Base.” In C. E. McLure, Jr. (ed.), The State Corporation Income Tax: Issues in Worldwide Unitary Combination. Stanford, CA: Hoover Institution Press.

National Tax Association (NTA). (1922). "Report of Committee on the Apportionment Between States of Taxes on Mercantile and Manufacturing Business," Proceedings of the National Tax Association 198-212.

Sørensen, P. B. (2004). "Company Tax Reform in the European Union," International Tax and Public Finance, $11(1), 91-115$.

Streamlined Sales Tax Project. (2003). Available at www.streamlinedsalestax.org.

Union of Industrial and Employers' Confederations of Europe (UNICE). (2000). "UNICE Memorandum on Cross-Border Company Taxation Obstacles in the Single Market."

Weiner, J. E. (1992). "Tax Coordination and Competition in the United States of America." In Commission of the European Communities, Report of the Committee of Independent Experts on Company Taxation. Luxembourg.

Weiner, J. M. (1994). "Company Taxation for the European Community: How Subnational Tax Variation Affects Business Investment in the United States and Canada." Ph.D. dissertation, Harvard University.

Weiner, J. M. (1996). "Using the Experience in the U.S. States to Evaluate Issues in Implementing Formula Apportionment at the International Level." Tax Notes International 23, 2113-2141; also available at www.ustreas.gov/ota/ota83.pdf.

Weiner, J. M. (2001). “The European Union and Formula Apportionment: Caveat Emptor," European Taxation $41,380-388$. 